\title{
A Comparative Analysis of Generic Structure Features in the News on Hong Kong National Security Law Between Chinese and American Newspapers The Case of People's Daily and The Washington Times
}

\author{
Zhuo Peng ${ }^{1, *}$
}

\author{
${ }^{1}$ School of Foreign Languages, Shaoguan College \\ *Corresponding author. Email: Tainiflick20@163.com
}

\begin{abstract}
At present, few scholars have made a comparative study on the news discourse of Hong Kong National Security Law between Chinese and American newspapers, and few scholars have systematically revealed the generic structure features of such discourse. In view of this, this study selects 20 pieces of news on Hong Kong National Security Law respectively from People's Daily and The Washington Times to compare their differences in generic structure features and the causes. It is found that the former reflects the objectivity, pertinence, focalization of news reports and the firm stance of defending Hong Kong National Security Law, while the latter reflects the storytelling nature, subjectivity, and richness and breadth of news content; these differences are caused by the different communicative purposes of the two newspapers. This study can provide enlightenment for the discourse construction of Chinese newspapers when reporting the Hong Kong National Security Law, and also contribute to extending the research field of generic structure.
\end{abstract}

Keywords: Hong Kong National Security Law, Chinese and American newspapers, generic structure features, comparison, communicative purposes

\section{INTRODUCTION}

From June 2019, Hong Kong has suffered from social unrest caused by the legislative amendment. In order to maintain the social stability of Hong Kong and the steadiness of the rule of "one country two systems", the 20th session of the Standing Committee of the 13th National People's Congress of China voted and passed the Law of the People's Republic of China on Safeguarding National Security in the Hong Kong Special Administrative Region (hereinafter referred to as the National Security Law). During the deliberation of the law by the National People's Congress, Chinese and American newspapers made a lot of reports on the law. At present, few scholars have analyzed the discourse of National Security Law reports. We don't know much about the structure and characteristics of such reports, at the same time, we don't know the discourse differences between Chinese and American newspaper reports on the law. In view of these, the paper intends to make a comparative study on the generic structure characteristics of news on Hong Kong National Security Law between
People's Daily and The Washington Times, in order to reveal their differences and the causes, and so as to provide enlightenment for writing news reports on the National Security Law in Chinese newspapers, and also contribute to extending the research field of generic structure.

\section{THE THEORY OF GENERIC STRUCTURE POTENTIAL}

Hasan puts forward the theory of Generic Structure Potential in the field of systemic functional linguistics. This theory holds that discourse is composed of some structural moves based on specific semantic sequence relations [1]. For example, the generic structure of teacher-students' question-answer sequence in classroom often consists of three moves: Teacher's Question $\wedge$ Student's Answer ^ Teacher's Feedback; the generic structure of selling and buying communication is generally made up of the following moves: (Greeting) ${ }^{\wedge}$ (Sales Initiation) $\wedge^{\wedge}$ (Sales Enquiry) ${ }^{\wedge}$ Sales Request $\wedge$ Sales Compliance ${ }^{\wedge}$ Sale $^{\wedge}$ Purchase $^{\wedge}$ Purchase Closure 
(^finis) [2]. Generic structure is composed of essential and optional moves [1]. For example, the above three moves of teacher-students' question-answer sequence are all essential ones, while the first three moves of selling and buying communication are optional ones. Genre is defined by essential moves, that is, texts with the same essential moves belong to the same genre; optional moves may not arise in specific texts, which contributes to the textual variation in the same genre [3]

At present, there are not many studies on the generic structure of news discourse. And these studies reflect three research directions: the generic structure of specific news discourse, comparative studies on the generic structure of news discourse in different newspapers, and the teaching application of the generic structure of news discourse. In the first direction, scholars focus on a certain kind of news discourse, such as assassination news [4], disaster news [5], economic news [6], etc., and they generalize generic structure of them. In the second direction, scholars compare the differences of generic structure of news on the same topic in different newspapers, such as the comparison of generic structure of Belt and Road Initiative news in Chinese and American newspapers [7], and the comparison of generic structure of air disaster news in Chinese and American newspapers [8], etc. In the third direction, scholars explore the applied approaches and effectiveness of generic structure in English teaching, such as the application of generic structure in teaching listening [9] and training pragmatic competence [10].

To sum up, first of all, few researches deal with the news discourse on the National Security Law, let alone study the generic structure features of such discourse; secondly, news discourse of different languages and different topics has its own unique generic structure features [11], [8], which indicates that there are different generic structure features between English and Chinese news on the National Security Law, however, few scholars have touched upon this field. Finally, various generic structure features will reflect different communicative purposes [12], a comparative analysis of the generic structural features of English and Chinese newspaper news on National Security Law will help to understand the different communicative purposes of foreign and Chinese news organizations, and provide an in-depth explanation for the causes of the differences in generic structure features. In view of the above reasons, this paper intends to make a comparative analysis of the generic structure features of the news on Hong Kong National Security Law in People's Daily and The Washington Times, so as to reveal the different features and their causes.

\section{A COMPARATIVE ANALYSIS OF GENERIC STRUCTURE FEATURES}

In this study, the researcher selects the news on mass basis, justification and applicability of National Security Law in People's Daily and The Washington Times from May to July 2020 as the data sources, and randomly picks out 20 pieces of news from the two newspapers respectively to compose Chinese and English corpora, and makes comparative analysis of the differences of generic structure features of the discourse in the two corpora above.

A comprehensive survey of the news discourse on National Security Law in the two newspapers shows that the generic structure is composed of eight moves: title, dateline, lead-in, lead-in supplement, background, reaction, secondary point and author's comment. The following is a comparative analysis of the features of eight moves in two newspapers.

Title is used for a general introduction to the news content, and all news in Chinese and English corpora has titles. The titles in the news of People's Daily tend to be formed by imperative sentences, such as "Resolutely Oppose the US's Gross Interference in Hong Kong Affairs", "Strongly Oppose the US's Signing of the Socalled Hong Kong Autonomy Act into Law" and "Never Allow Double Standards to Handicap International Justice". The titles in the news of The Washington Times are inclined to be composed of declarative sentences, such as "Hong Kong Media Tycoon Says City Now 'dead", "China Approves Contentious Hong Kong National Security Law", "Pompeo Says Hong Kong Is No Longer Autonomous from China". From the different composition of titles, it can be seen that People's daily is extremely resolute in defending the National Security Law; while The Washington Times generally resorts to a narrative way to compose news titles, and their implied attitudes do not tend to be firm.

A dateline mainly introduces the time of news releases, the author and his / her organization, etc. All the news in the Chinese and English corpora includes the move of a dateline. However, the datelines of the news in People's Daily only tend to reveal authors' organizations and the time of news releases, such as "Xinhua News Agency, Hong Kong, June 27", "Xinhua News Agency, Beijing, July 15" and "People's Daily Agency, Beijing, June 29". The datelines of the news in The Washington Times tend to show the authors' names, their organizations and the time of news releases, for example, "By Stephen Dinan, The Washington Times, Thursday, May 21, 2020", "By Zen Soo, Associated Press, Friday, June 19, 2020". It can be seen that People's Daily focuses more on institutional responsibilities for releasing the news, and news organizations will strictly review the news content, and the views delivered by the news are inclined to reflect a higher degree of unity; The 
Washington Times concentrates more on individual responsibilities for releasing the news, so it often covers news discourse with diverse or even opposite views.

A lead-in is used to briefly introduce the core information of the news, usually including several or all of the news elements as who, what, when, where, why and how. All news in the above Chinese corpus contains the move of a lead-in, which is often expressed by means of reporting other people's views. For example, "on the 27 th, people from all walks of life in Hong Kong said that the so-called Hong Kong Autonomy Act passed by the US Senate grossly interfered in Hong Kong's affairs, and infringed the interests of China and the people of Hong Kong, and seriously violated the basic norms of international conventions and international relations". In the meantime, there are nineteen pieces of news that contain the move of a lead-in in the above English corpus. The authors usually introduce lead-ins as their views, such as "president Trump signed legislation Tuesday sanctioning Chinese officials and entities for China's 'repressive actions' against the people of Hong Kong, and issued an executive order ending the territory's preferential treatment by the US". It can be seen that People's Daily introduces the core information of news by reporting others' views, so as to reflect the objectivity of the news reports, while The Washington Times mainly introduces the core information of news by means of subjective statements or comments.

A lead-in supplement is to expand the core information introduced by the lead-in, including introducing the main event content, results or explaining the core information. Only one piece of news in the Chinese corpus contains the lead-in supplement. For example, after the introduction of the lead-in "to stop the chaos of education in Hong Kong, the most urgent thing is to chop off these 'black hands' which extend into the campus and give the youth a quiet campus". The lead-in is supplemented by the description of how to realize the goal mentioned in lead-in: "the decision made by the country to promote the Hong Kong National Security Law will bring the long lost serenity back to Hong Kong”. While in the English corpus, there are nine pieces of news containing lead-in supplements. For example, a lead-in in a piece of news mentioned "US plans to withdraw the former British colony's preferential trade and financial status Hong Kong has enjoyed since it reverted to Chinese rule 23 years ago". And this news is followed by the supplement for explaining the lead-in: "the move does not carry any immediate penalties, which would have to be decided by president Donald Trump in consultation with Congress, but the administration sees it as putting China on notice that Hong Kong's perks are in jeopardy". To sum up, in a lead-in supplement, an author tends to express his / her own views. People's Daily seldom uses lead-in supplements, which can reduce the subjectivity of the news and authors' emotional intervention.
A background mainly introduces the things happening before the core event [6]. Five pieces of news in the Chinese corpus contain a move of the background, for instance, "as we all know, since June last year, the anti-China forces in Hong Kong have openly and vigorously advocated 'Hong Kong independence', 'selfdetermination' and 'referendum', and engaged in sabotage and separatist activities in Hong Kong, which not only led to the traffic standstill, shop closures, people's life in distress, but also the most basic safety of life and property could not be guaranteed". While in the English corpus, there are fourteen pieces of news containing a move of the background, for example, "he (Jimmy Lai) founded the Apple Daily tabloid in 1995, ahead of Britain's handover of Hong Kong to China". From the number of the news with the background moves, we can see that People's Daily focuses more on the state and development of the core events, while The Washington Times tends to report the news by means of storytelling and focuses on the context of the news.

Reaction refers to the remarks and opinions expressed by relevant people and organizations in news events [13]. There are seventeen pieces of news that contain a move of reaction in the Chinese corpus. For instance, "the editorials of Ta Kung Pao newspaper pointed out that behind all the chaos in Hong Kong, there are American "black hands"'. While there are nineteen pieces of news which comprise a move of reaction in the English corpus. For example, "Mike Pompeo said in a statement, 'We can no longer distinguish between the export of controlled items to Hong Kong or to mainland China"'. It can be seen that both newspapers use a lot of moves of reaction to introduce other people's views, so that the author can not only avoid too much explicit intervention of his / her own voice, but also borrow others' views to imply his / her own position.

Secondary points refer to the secondary events vis-avis the core events of news reports, which are related to the latter, but not independent enough to stand alone [13]. There are only four pieces of news that contain secondary points in the Chinese corpus. For example, in certain news, the author indicated that the passage of Hong Kong National Security Law caused the United States to impose political repression on China. Basing on such a core event, the author added a secondary point like this: "the Universal Declaration of Human Rights points out that when everyone exercises his rights and freedom, he is only subject to the restrictions determined by laws, and the only purpose of determining such restrictions is to ensure everyone's acknowledgement of and respect for the other's rights and freedom". There are thirteen pieces of news in the English corpus, which contain a move of the secondary point. For example, when talking about the core event of Trump's signing of the Hong Kong Autonomy Act in response to the Hong Kong National Security Law, a piece of news introduced the secondary point that Trump was under various domestic pressure: 
"the president has been under increasing criticism, including by Mr. Biden, for his handling of the coronavirus pandemic that originated in China". From the number of secondary points in the two newspapers, we can see that the news in People's Daily focuses on the core events and has few secondary points, so the length of the news is generally short; while the news in The Washington Times has more secondary points, and therefore, the length of the news tends to be longer.

The author's comments refer to the author's evaluation of the events or people reported in the news. Seven pieces of news in the Chinese corpus contain the author's comments, for example, "Hong Kong belongs to China, no one cares more about the prosperity and stability of Hong Kong and the well-being and rights of Hong Kong compatriots than the Chinese government and people do". There are thirteen pieces of news that contain the move of author's comments in the English corpus, for example, "Hong Kong's uncertain future is putting it at a disadvantage with other Asian destinations that are competing to attract foreign investment, such as Singapore and Tokyo". By comparison, we can see that the authors of the news in People's Daily seldom express their own comments, and the news content reflects higher objectivity, while the authors in The Washington Times do to the contrary.

\section{THE CAUSES OF DIFFERENCES IN GENERIC STRUCTURE FEATURES}

Basing on the above analysis, we can draw the following conclusions. First of all, the news of People's Daily tends to comprise titles formed by imperative sentences and highlight the institutional responsibilities for the news releases, and the views in the news reflect a higher degree of unity and an extremely firm position of defending the National Security Law. Secondly, the news in People's Daily is inclined to introduce the core information by reporting others' views which are usually shown by a move of reaction, but the news seldom resorts to the move of lead-in supplement and scarcely introduces the authors' comments, which therefore reflect the objectivity of the news reports. Finally, the news in People's Daily focuses more on the state and development of core events, and uses few secondary points for expanding the content of the news, which reflects the pertinence and focalization of news reports.

The generic structure features of the news in The Washington Times are as follows. first of all, the news writers tend to present titles by means of narrative sentences and pay attention to the complete sequence of the news content, which therefore reflect the storytelling nature of the news reports. Secondly, the news writers are inclined to introduce others' views by the move of reaction, and they mainly use the subjective statements or comments to introduce the core information of the news, and they relatively use more lead-in supplements and their own comments, all of these reflect the high subjectivity of the news reports. Finally, the news indicates its focuses on the individual responsibility for the reporting, therefore, it often covers a variety of views or even opposing views. The news tends to include relatively more secondary points and its length is generally long, which reflects the richness and breadth of the news content.

Different generic structure features can reflect various communicative purposes [12], therefore, the above differences between the two newspapers are determined by communicative purposes. In the countering news reports on Hong Kong National Security Law between Chinese and American newspapers, the latter are the initiator, while the former are the responder. As a loyal spokesman of the Chinese government, People's Daily will respond strongly to the American news containing derogatory comments on Hong Kong National Security Law, which reflects the former's communicative purpose of firmly upholding the law. At the same time, People's Daily reduces the subjectivity of its news by reporting others' views, so as to achieve the purpose of enhancing the persuasiveness and credibility of its news. In addition, the news in People's Daily concentrates on the core events and has high degrees of pertinence and focalization, so that it can achieve the purpose of enhancing the strength of countering.

In contrast, the news in The Washington Times focuses on the complete sequence of the content, which reflects the characteristics of storytelling. The reason is that the news aims to construct a complete informational basis for derogating from the National Security Law and try to enhance the credibility of its views. At the same time, because the main purpose of the news is to criticize the National Security Law, the news presents a lot of authors' comments, which reflects a high degree of subjectivity. In addition, rich and extensive news content in The Washington Times helps to provide a variety of information support for derogating from the law and also helps to stir up trouble from all aspects.

\section{CONCLUSION}

Taking the People's Daily and The Washington Times as examples, this study explores the differences in the generic structure of the news on Hong Kong National Security Law between the two newspapers, and investigates the causes of the differences. The study shows that the generic structure of the news in People's Daily reflects the objectivity, pertinence, focalization and the firm stance of defending Hong Kong National Security Law, while the generic structure of The Washington Times reflects the storytelling features, subjectivity, richness and breadth of news content. These differences are caused by the different communicative purposes of the two newspapers. By analyzing these differences, we can gain insight into the characteristics 
and motives of the news in The Washington Times and reveal their nature of derogating from Hong Kong National Security Law, which can provide enlightenment for the People's Daily and other Chinese newspapers to better respond to the attacks of The Washington Times, and contribute to the construction of the discourse system for defending China's social institution. At the same time, this study focuses on the generic structure of news reports, which helps develop the traditional generic structure research and extend the breath of it.

\section{ACKNOWLEDGMENTS}

Research for this study is sponsored by Guangdong Province Educational Science Project (No. 2020GXJK071); Shaoguan College Research Project (No. SZ2020SK02).

\section{REFERENCES}

[1] M. A. K. Halliday and R. Hasan, Language, Context, and Text: Aspects of Language in a Social-semiotic Perspective, Oxford University Press, Oxford, 1989.

[2] Z. L. Hu, Y. S. Zhu, D. L. Zhang and Z. Z. Li, An Introduction to Systemic Functional Linguistics, Peking University Press, Peking, 2017.

[3] H. P. Liu and W. P. Guo, The Predictive Function of Register to Generic Structure, Journalism Lover (10) (2011) 108-109. DOI: https://doi.org/10.16017/j.cnki.xwahz.2011.10.002

[4] T. A. van Dijk, News Analysis: Case Studies of International and National News in the Press, Lawrence Erlbaum Associates Publishers, Hillsdale, 1988.

[5] A. Bell, The Discourse Structure of News Stories, in: I, T. A. van Dijk (Ed.), Discourse Studies, SAGE, London, 2007, pp. 58-89.

[6] Y. H. Wu, A Corpus-based Study on the Generic Structure Potential of the English Economy News, Journal of Qiqihar University (1) (2008) 96-98. DOI: https://doi.org/10.13971/j.cnki.cn231435/c.2008.01.028

[7] G. D. Jiang and J. Wang, A Contrastive Study of "One Belt, One Road" English and Chinese News Generic Structures, Journal of Hangzhou Dianzi University 13(6) (2017) 68-71. DOI: https://doi.org/10.13954/j.cnki.hduss.2017.06.012

[8] H, Zhao and C. Li, Attitudes in Sino-US Straight Disaster News Reports Based on Generic Structure - With Examples of Breaking Air Disaster Reports in China Daily and The New York Times, Journal of China University of Mining \& Technology (1) (2013) 137-144.
[9] J. D. Mao and H. H. Zhu, An Application of the Generic Structure Potential Theory to the Teaching of English News Listening, Journal of Zhejiang Ocean University 34(6) (2017) 85-90.

[10] E. Ifantidou, Genres and Pragmatic Competence", Journal of Pragmatics 43(1) (2011) 327-346. DOI: https://doi.org/10.1016/j.pragma.2010.07.016

[11] F. Xu, A Research Overview of the Generic Structure of English Academic Discourse (19802012), Journal of Southeast University 15(5) (2013) 128-133. DOI: https://doi.org/10.13916/j.cnki.issn1671511x.2013.05.010

[12] L. H. Liu, Martin's Contributions to Genre Studies, Foreign Language Research (1) (2019) 12-17. DOI: https://doi.org/10.16263/j.cnki.231071/h.2019.01.003

[13] Y. Zhang, An Analysis of the Generic Structure Potential of English Radio News, Journal of Zhejiang University of Media and Communications 20(5) (2013) 105-109. DOI: https://doi.org/10.13628/j.cnki.zjcmxb.2013.05.017 